\title{
"We're Made Criminals Just to Eat off the Land": Colonial Wildlife Management and Repercussions on Inuit Well-Being
}

\author{
Jamie Snook ${ }^{1,2, *(0)}$, Ashlee Cunsolo ${ }^{3}{ }^{\circ}$, David Borish ${ }^{2}{ }^{\oplus}$, Chris Furgal ${ }^{4}$, James D. Ford ${ }^{5}{ }^{(}$, \\ Inez Shiwak ${ }^{1}$, Charlie T. R. Flowers ${ }^{1}$ and Sherilee L. Harper ${ }^{2,6}{ }^{(D)}$ \\ 1 Torngat Wildlife Plants and Fisheries Secretariat, Happy Valley-Goose Bay, NL A0P 1E0, Canada; \\ inez.mj.shiwak@gmail.com (I.S.); charlieflowers@gmail.com (C.T.R.F) \\ 2 Department of Population Medicine, University of Guelph, Guelph, ON N1G 2W1, Canada; \\ dborish@uoguelph.ca (D.B.); sherilee.harper@ualberta.ca (S.L.H.) \\ 3 Labrador Institute, Memorial University, Happy Valley-Goose Bay, NL A0P 1E0, Canada; \\ ashlee.cunsolo@mun.ca \\ 4 Indigenous Environmental Studies \& Sciences Program, Trent University, Peterborough, ON K9L 0G2, \\ Canada; chrisfurgal@trentu.ca \\ 5 Priestley International Centre for Climate, University of Leeds, Leeds LS2 9JT, UK; j.ford2@leeds.ac.uk \\ 6 School of Public Health, University of Alberta, Edmonton, AB T6G 1C9, Canada \\ * Correspondence: jamie.snook@torngatsecretariat.ca or jsnook@uoguelph.ca; Tel.: +1-709-896-6041
}

Received: 28 August 2020; Accepted: 26 September 2020; Published: 3 October 2020

\begin{abstract}
Across Inuit Nunangat, Inuit rely on wildlife for food security, cultural continuity, intergenerational learning, and livelihoods. Caribou has been an essential species for Inuit for millennia, providing food, clothing, significant cultural practices, and knowledge-sharing. Current declines in many caribou populations - often coupled with hunting moratoriums - have significant impacts on Inuit food, culture, livelihoods, and well-being. Following an Inuit-led approach, this study characterized Inuit-caribou relationships; explored Inuit perspectives on how caribou have been managed; and identified opportunities for sustaining the Mealy Mountain Caribou. Qualitative data were collected in Rigolet, Nunatsiavut, Labrador, Canada through 21 in-depth interviews and two community open houses. Data were analyzed using constant comparative methods and thematic analysis. Rigolet Inuit described: how conservation management decisions had disrupted important connections among caribou and Inuit, particularly related to food, culture, and well-being; the socio-cultural and emotional impacts of the criminalization of an important cultural practice, as well as perceived inequities in wildlife conservation enforcement; and the frustration, anger, and hurt with not being heard or included in caribou management decisions. These results provide insights into experiences of historic and ongoing colonial wildlife management decisions, and highlight future directions for management initiatives for the health and well-being of Inuit and caribou.
\end{abstract}

Keywords: caribou; co-management; Inuit well-being; wildlife management; cultural continuity; Northern Canada; indigenous peoples

\section{Introduction}

Indigenous Peoples around the world continue to rely on wildlife and the natural environment for food security [1], cultural continuity [2], intergenerational learning and sharing [3], livelihoods [4,5], and physical, mental, emotional, and spiritual health, and often have deep and enduring relationships with the lands, waters, and wildlife in their homelands [6,7]. Human-induced activities, such as resource extraction [8], deforestation [9], and climate change [10-12], are threatening these relationships through 
habitat degradation and species decline [7,13-15]. Indeed, a recent global assessment conducted by the Intergovernmental Science-Policy Platform on Biodiversity and Ecosystem Services [16] documented and reported rapidly deteriorating ecosystems and biodiversity loss. The pressures from ecosystem degradation, combined with the need for Indigenous harvesting, threatens the foundations of Indigenous livelihoods, food security, and health and well-being worldwide [16].

Within Canada, First Nations, Inuit, and Métis Peoples continue to have interconnected relationships with a broad range of wildlife species that are at risk from a variety of stressors, including climate change and human activities. For instance, one important keystone species experiencing declines across Canada is the woodland caribou (Rangifer tarandus), of which the majority of herds across the country are currently reported to be in decline [17]. The 51 different woodland caribou herds in Canada are spread throughout most provinces and territories, and are affected by habitat disturbances [18,19], predation [20], diseases [21], and climate change [10,11]. Of the 37 populations for which there are trend data available in Canada, $81 \%$ are declining $(n=30 / 37$ populations) [17]. As such, the Committee on the Status of Endangered Wildlife in Canada assessed the species as "Threatened" in 2002 and, subsequently, listed them as "Threatened" under the Species at Risk Act in 2003, a status that continues to this day.

For the Indigenous Peoples across Canada who rely on caribou for food, culture, livelihoods, and well-being, this decline in woodland caribou populations-often coupled with a resulting hunting moratorium-has significant health and well-being impacts, and raises serious concerns. Inuit and their ancestors across Inuit Nunangat (Inuit homelands in Canada) have actively harvested and relied on caribou for thousands of years, utilizing the meat and skin for valuable food sources and clothing, and the bones and antlers for tools and carvings [22]. Despite this critical role in Indigenous life, caribou are generally managed through the popularized North American Model of Wildlife Conservation (NAM) [23], which is anchored in a colonial framework in which Indigenous Peoples have little to no authority. Indeed, Indigenous scholars have highlighted many limitations of its use in Indigenous territories [24], critiquing the model by commenting that "one cannot imagine a framing more centered on white male hunters than that contained in this historical overview for the origins of wildlife conservation in the United States and Canada" [25].

In the Nunatsiavut Land Claims Settlement region of Northern Labrador, Canada, caribou remain essential for food security, cultural connections, and overall health and well-being. Yet, caribou populations have been declining, with three different caribou populations listed under the Species at Risk Act: Torngat Mountains Caribou (endangered) [26], George River Caribou (endangered) [26], and the Mealy Mountain Caribou (threatened) [27]. For each of these herds, colonial management strategies have been imposed in order to protect the herds from further decline. For example, the Newfoundland Wildlife Division created strategies to manage the Mealy Mountain Caribou in this region with the first attempt to close the hunting season in 1959 [28]. Between 1959 and 1975, wildlife biologists were unable to convince the provincial government to follow full recommendations to close the hunt, with intermittent restrictions placed on harvesting during this time. In 1976, a total hunting ban was enacted, and has been in place ever since, with the exception of one licensed hunt in 1989 [29]. Prior to 1975, the Mealy Mountain Caribou were foundational for the food security, identity, and well-being of Inuit in the region; however, with concerns of a declining population, a total hunting moratorium was issued in 1975 by the Provincial government-with no warning to, input from, or consent by Inuit in the region-which put an immediate end to the legal harvest of Mealy Mountain Caribou [28]. The long-term hunting ban on the Mealy Mountain Caribou has had important implications for Inuit living in close proximity to the herd, including those in Rigolet, Nunatsiavut [28], which is the main focus of this study.

While caribou have been identified as essential for Inuit physical, mental, and emotional health and well-being, as well as identity and cultural continuity across the Circumpolar North, little research has examined the ways in which management strategies affect Inuit lives, livelihoods, and well-being through their insertion in the relationship between Inuit and caribou. Working in partnership with 
Inuit in Rigolet, Nunatsiavut, this research documents Inuit knowledge to: (1) characterize Rigolet Inuit relationships with Mealy Mountain Caribou; (2) understand Inuit perspectives on how these caribou have been managed; and (3) identify opportunities for sustaining the Mealy Mountain Caribou population, while at the same time promoting Inuit well-being. While this research focuses on a case study from Rigolet, the findings provide insights into the impacts of wildlife laws, stemming from colonial approaches to management, across Canada and the Circumpolar North $[30,31]$ and the ways in which Indigenous Peoples globally are experiencing cultural disruptions resulting from wildlife declines and related wildlife management decisions.

\section{Methods}

\subsection{Rigolet, Nunatsiavut, Labrador}

There are over 65,000 Inuit in Canada, 73\% of whom live within the 53 Inuit Nunangat communities [32], located in the Inuvialuit Settlement Region (Northwest Territories and Yukon), Nunavut, Nunavik (Quebec), and Nunatsiavut (Labrador). The Nunatsiavut Land Claims Settlement region has approximately 2500 beneficiaries living within five coastal communities (North to South: Nain, Hopedale, Postville, Makkovik, and Rigolet); 2200 living in the central Labrador communities of North West River, Mud Lake, and Happy Valley-Goose Bay; and 2400 living in other locations across Canada [33].

Rigolet $\left(54^{\circ} 10^{\prime} 21.3204^{\prime \prime} \mathrm{N}, 58^{\circ} 29^{\prime} 3.21^{\prime \prime} \mathrm{W}\right)$ (Figure 1) is the southern-most community in the Nunatsiavut region, and is home to 305 people, $90 \%$ of whom identify as Inuit [32,34]. Rigolet Inuit continue to rely on the lands, waters, plants, and animals in the region for sustenance, cultural expression, intergenerational knowledge-sharing and the passing on of land-based knowledge, and overall well-being [35,36]. The history of colonialism and contact in Rigolet spans over 300 years, including contact with explorers, traders, the Hudson's Bay Company, and the fishing industry [37]. Rigolet was incorporated within the province of Newfoundland and Labrador in 1977, and was later included within the Labrador Inuit Land Claim Agreement in 2005 [38]. Rigolet is located at the mouth of Lake Melville on the mid-Labrador coast, situated within a northern Boreal ecosystem. Many Rigolet families have historic ties to resettled villages throughout the Groswater Bay area and on the southside of Lake Melville, directly within the range of the Mealy Mountain Caribou, and connected to the Akami-Uapishk ${ }^{\mathrm{u}}$-KakKasuak-Mealy Mountain National Park Reserve (Figure 1).

The Mealy Mountain woodland caribou sub-population is one of the herds in close proximity to Rigolet (Figure 1), and has an estimated population of 1696 caribou [39]. As sedentary caribou, they move less than migratory caribou and do not venture north of the tree line to calve. The habitat of these caribou is relatively intact with very few human disturbances [29,40]. The herd size has been estimated 13 times since 1958 [40], and while the population has estimated to be as high as 2500 and as low as 500 caribou during this time, there has been inconsistency in the research methods, budgets, and personnel involved over this time period. Today, the ongoing monitoring of the herd by government officials - without engaging Inuit—and the continued hunting ban have resulted in significant impacts for Inuit in region and no meaningful strategy for future sustainable utilization of the herd by Inuit.

\subsection{Research Approach}

While Indigenous Peoples around the world have always relied on their Indigenous knowledge to guide their relationships with wildlife [41], this knowledge has not been included in colonial wildlife management strategies, which is often biased toward positivist, Western-based approaches in conservation and wildlife management [42-44]. Co-management boards created from modern day land claim agreements-one strategy to incorporate Indigenous leadership into wildlife management and decision-making - serve to promote Indigenous knowledge as a critical consideration in wildlife management [45-47]. For example, the Torngat Wildlife and Plants Co-management Board was 
created as a result of the Labrador Inuit Land Claim Agreement signed in 2005, and is comprised of appointees from the Nunatsiavut Government, the Government of Newfoundland and Labrador, and the Government of Canada. This research was as part of a larger caribou research program led by the Torngat Wildlife and Plants Co-Management Board in partnership and collaboration with Inuit community researchers in Rigolet and with academic researchers [48]. The approach intentionally aligned with Inuit Tapiriit Kanatami Research (ITK) National Inuit Research Strategy [49], and was reflected by Inuit: governing this research at multiple levels; ensuring the research was ethical and in line with community priorities; prioritizing Inuit access, ownership, and control over data and information; and continuing to further build capacity in Nunatsiavut research.

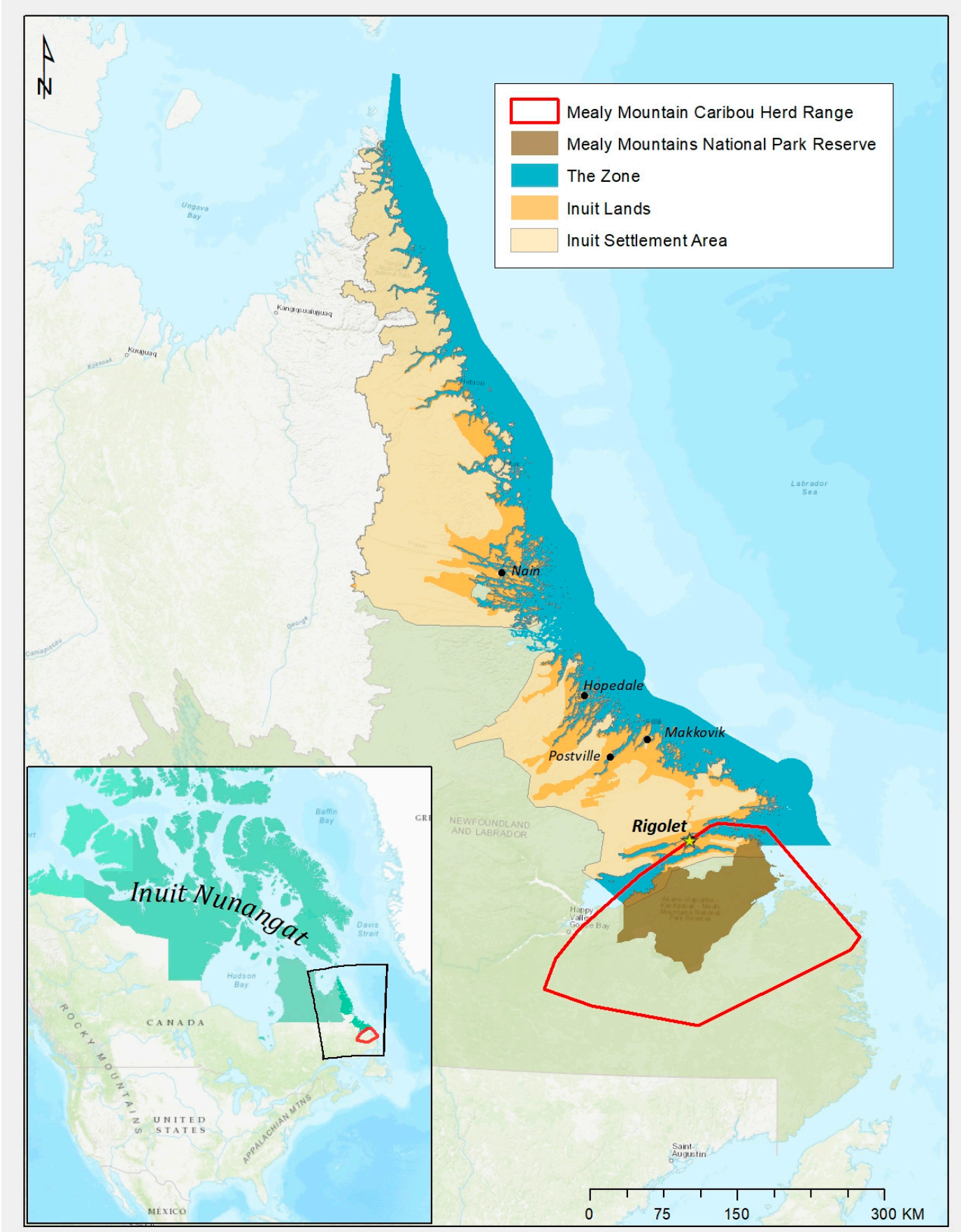

Figure 1. Map of the Labrador Inuit Settlement Region, the five Nunatsiavut communities, including Rigolet and its vicinity to the Mealy Mountain Caribou range. 


\subsection{Data Collection}

Given the complexities of socio-ecological research, the notable absence of past qualitative research understanding Inuit perspectives on the Mealy Mountain Caribou and related hunting ban, and an ongoing bias toward quantitative methods in the conservation and wildlife management fields $[50,51]$ our research team purposefully used multiple qualitative methods, including in-depth conversational interviews [52], participatory mapping [53], and a results sharing, validation, and prioritization session. Given the lack of past baseline data on the Mealy Mountain Caribou herd abundance and trends in harvesting, as well as the lack of research on the hunting moratorium and subsequent impacts on Inuit, qualitative inquiry provided the strongest option to discover both rich and new insights from this study.

Interview questions were co-developed with Inuit researchers, members of the community, the Torngat Wildlife, Plants, and Fisheries Secretariat, and academics. Interview questions were pre-tested for content and context, and covered the following topics: personal caribou stories, the meaning of caribou to people in Rigolet, caribou biological features, the health of the Mealy Mountain Caribou, threats to the caribou, perspectives on caribou management, effects of management decisions on health and well-being, and ideas regarding next steps to improve caribou management. Interviewees were recruited in January 2019 through a community open house and using an ongoing snowballing technique through conversation with community leaders, Elders, Mealy Mountain knowledge holders, and interview participants, specifically focusing on individuals who had experience hunting Mealy Mountain Caribou before the ban and/or knew the lands on which the caribou lived well. Two Rigolet Inuit research associates also provided contacts, introductions, and facilitated the interviews in the community. Interviews took place from January 29 to February 10, 2019 at a location preferred by the interviewee: most interviews took place in people's homes or in the community center. All interviews were audio recorded, with informed consent, and conducted in English at the participants' request (translators were available). Twenty-one interviews ( $n=6$ females and 15 males) were conducted with Inuit from Rigolet, producing $11 \mathrm{~h}$ and $9 \mathrm{~min}$ of recorded data for analysis (Table 1).

Table 1. Interview participants by age group in Rigolet, Nunatsiavut, Labrador ( $n=21$ interviewees).

\begin{tabular}{cc}
\hline Age Range & Number of Interviewees \\
\hline 20-29 years old & 0 \\
$30-39$ years old & 1 \\
$40-49$ years old & 3 \\
$50-59$ years old & 2 \\
$60-69$ years old & 5 \\
$70-79$ years old & 6 \\
$80+$ years old & 4 \\
\hline
\end{tabular}

The participatory mapping session occurred as part of a January 2019 community research open house and caribou storytelling event, before in-depth interviews were conducted. A group of seven people from among the larger open house attendees took an extended period of time to participate in the mapping session, which took place at the community center using 1:800,000 scale maps in a WGS84 projection. Each map was printed using a large format printer (each map was $88 \mathrm{~cm} \times 66 \mathrm{~cm}$ ). Each individual map was secured on a table for respondents to see the area in its entirety. Participants were invited to walk around the map and mark locations on the map with a marker, and provide narrative explanations of their map markings [54] from their lifetime of experiences. Common markings included caribou sightings, harvest sights, cabins, trapping areas, hunting routes, trapping routes, and significant geographical areas.

In March 2020, the research team held a result sharing, validation, and prioritization open house, open to all members of the community. There were 37 community members who attended and participated, 20 were female, and the age range was from 10 years old to over 75 years old. Of those 
who attended the community open house, six were also interview participants. This provided an opportunity to present preliminary results, for Inuit to engage with the data, and to record new insights or contradictions in the data. The open house was further complimented by a presentation to the Rigolet Inuit Community Government and key informants, including interview participants, from the community for their insights, reflections, and approval.

\subsection{Data Analysis}

All audio recordings from the interviews were transcribed by a professional transcription company and checked by at least one member of the research team for accuracy. All transcripts were uploaded to QSR International's NVivo 12 software [55], which was used to facilitate data organization, retrieval, and manual inductive and deductive coding [56]. The hybrid inductive and deductive coding approach [57] followed a constant comparative method [58], which involved the research team holding regular debriefs throughout the analysis to discuss the interviews and data. The team constantly compared concepts, codes, and themes within, between, and among the data. These debriefs were held throughout the research process, including after the initial open house, after each individual interview, after full completion of the interviews, after the results sharing and validation activities, and through the process of choosing key quotes to illustrate the main themes discovered through the analysis process. Authenticity and reliability of the results were supported by this team-based approach, and included researcher and team reflexivity and ongoing dialogue, and ground truthing and validating the results with Rigolet Inuit participants [59].

\subsection{Data Management and Consent}

This research was approved by the University of Guelph Research Ethics Board and the Nunatsiavut Government Research Advisory Committee. All participants provided informed oral and written consent. The Torngat Wildlife, Plants, and Fisheries Secretariat managed the data for this project. Data management procedures reflected ITK's National Inuit Research Strategy priority to ensure Inuit access, ownership, and control over data and information [49] by providing copies of all the data at the end of the project to the Rigolet Inuit Community Government and the Government of Nunatsiavut.

\section{Results}

Results from the participatory mapping session, based on extensive place-based knowledge, indicated several main themes: caribou are essential for Inuit culture, livelihoods, and food security; caribou management decisions have disrupted these Inuit-caribou connections; the socio-cultural and emotional impacts resulting from the criminalization of a cultural practice, the perceived inequities in caribou hunting ban enforcement, and the lack of meaningful engagement with Inuit in wildlife management decision-making; and potential pathways forward that would ensure a sustainable caribou population, while supporting and promoting the role of caribou in Inuit culture and well-being (Figure 2).

Through the in-depth interviews, Rigolet Inuit shared extensive knowledge of and stories about Mealy Mountain Caribou. The range of this knowledge spanned understandings of: caribou biology, ecology, and habitat; Inuit hunting values; management perspectives; interconnected changes in climate, environment, and herd abundance; and connections to food security and Inuit health and well-being. In the participatory mapping session, participants marked 33 points, 18 polylines, and 14 polygons of geographic significance related to caribou and caribou interactions. Sites marked as key points in the session included cabins, caribou sightings, historical moments, geographically significant points, and harvest sites. Sites marked as polylines included trapping routes, skidoo routes, hunting routes, caribou migration routes, and ice edge. Sites marked as polygons included caribou sighting areas, communities, historical hunting grounds, harvesting sites, and trapping grounds. Through these illustrations, participants in the mapping session documented a long-standing relationship to and knowledge of Mealy Mountain Caribou for Rigolet Inuit (Figure 2). 


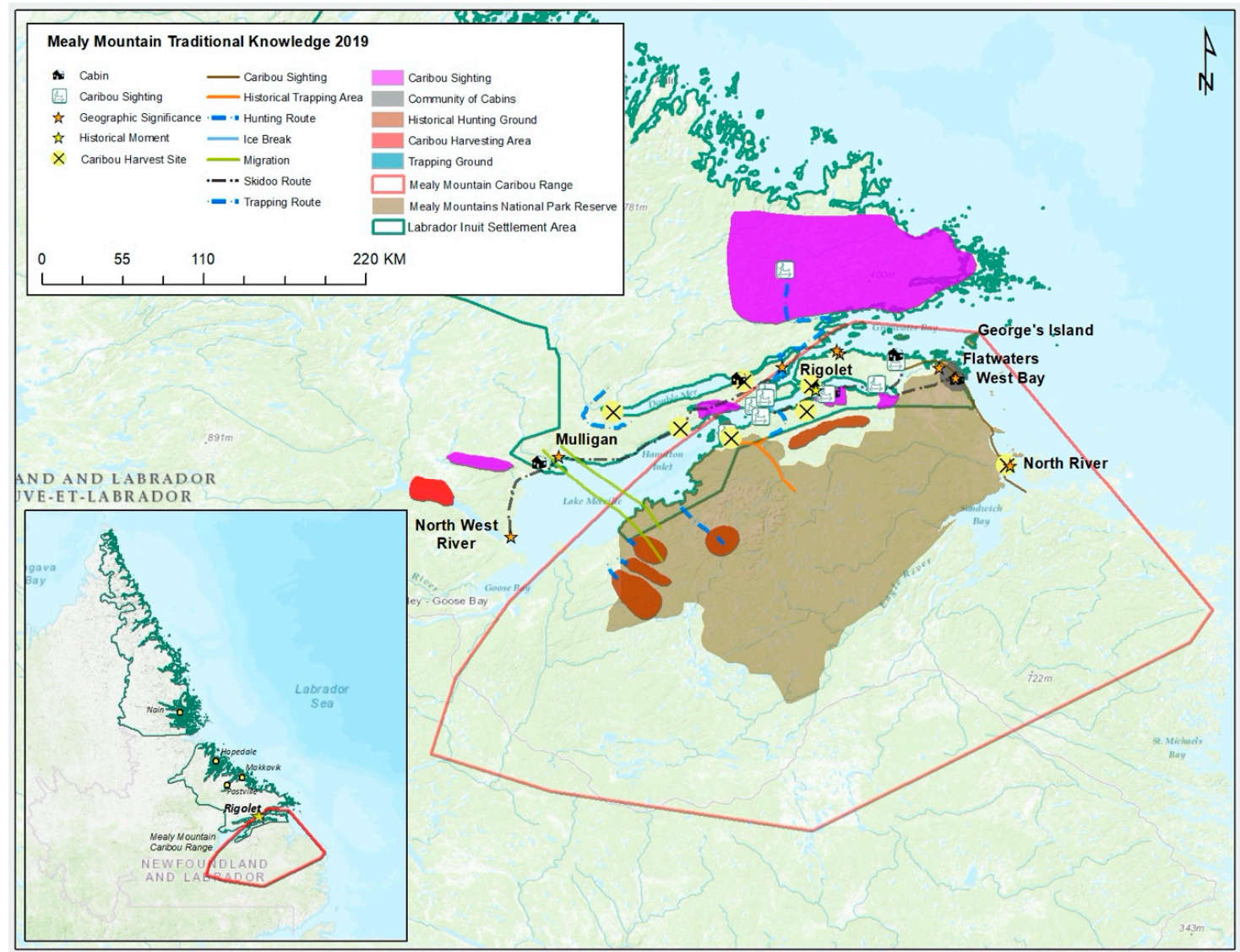

Figure 2. Geographic data provided by Rigolet Inuit in a participatory mapping activity in Rigolet in January 2019 identifying knowledge related to range, habitat, behavior, and Inuit-caribou interactions.

\section{1. "Part of Our Culture Down Here": Rigolet Inuit and Mealy Mountain Caribou}

Many participants shared personal memories and stories about significant moments with caribou, such as their first hunt, traveling via dog teams, traveling long distances on snowshoes, and experiencing extreme weather exposure during the hunts (Figure 2). Rigolet Inuit described the "hard work" associated with hunts in the past, but reflected fondly on the entire experience as "fun", a source of "pride", and "excit[ing]", "happy", and "healthy" experiences. For example, as one participant shared, "I was only a young fellow first time when I went across there, about 14 or 15, with the old man over to Mealy Mountain. That was back in the "60s." Another interviewee explained, "One of my favorite stories relating to caribou? Hunting around with my father, killing caribou to eat, living off the caribou all my life."

The majority of participants described the ways in which activities involving caribou were interwoven with local livelihood and survival: "It was more of what you did to survive. You either went and you got your caribou or your seal or your birds. But it wasn't easy to do but you did it 'cause your survival depended on it." One life-long hunter explained:

"A hunter person without a gun is the same as the city man without a job, you know, a high-powered city man without a big job. If you take his job away, he got nothing to eat. If you take my gun away, I got nothing to eat."

Other participants highlighted the link between caribou and Inuit identity. Participants shared throughout the interviews, "that [caribou hunting] is part of who we are. Caribou ... that's our food. ... caribou is our staple food, or was, or still is if we can get it." As another individual explained, "We've always hunted the Mealy Mountain Caribou. That sustained our family for generations and generations and generations." 
Given the links between caribou and Rigolet life and culture, many participants were openly concerned that part of their culture and knowledge related to caribou is at risk of eroding, and that, in particular, the introduction of the hunting ban in 1975 changed the ways in which knowledge of the Mealy Mountain Caribou is being passed on (Figure 2). As one hunter explained, "My buddy's father, he's older than me, and he was probably the last generation that went up on the mountains caribou hunting, legally." Another participant stated:

"There's not too many people left in this community here that actually participated in that hunt, they're mostly all dead, they're all old and gone. So, I mean you know, it's going to be a big part of who we are and our identity, when that goes away."

\section{2. "I Was Raised to Learn How to Share My Stuff": Caribou, Food, Culture, and Well-Being in Rigolet}

Participants in this study were unified in their experiences of missing caribou meat. People shared enthusiasm around the taste of caribou. For instance, one participant explained that "it's delicious. The best meat ever. And that's telling the truth." Others talked about their preference for it, the beneficial health aspects of consuming caribou meat, and the many ways it can be prepared. As one participant noted, "like we fry and stew and bake and dry it and roast it; all ways. Make cakes."

Many people also discussed the nutritional benefits of consuming caribou meat, and described how it made people feel physically, mentally, and emotionally healthy. As one participant explained, "From the health side, I think that's really lean meat. Caribou is like, really lean meat. So really tasty meat and things, so I think there's things we just miss out on [as a result of the hunting ban]." Another participant stated:

"I think there's a loss in that opportunity to teach and to learn, as well as to have more of an appreciation for a local diet, a healthy diet, an organic diet. Those things aren't said to children often-you're eating organic food today."

These experiences of missing eating caribou meat were compounded by disruptions to cultural practices that were changing stemming from the inability to travel and hunt in the Mealy Mountains. People indicated that without the possibility of hunting caribou, their patterns and frequency of use, and reasons for spending time in the Mealy Mountains had changed. As one person explained, "At the end of the day, you have to have a reason to go [out on the land]." Another hunter explained further that caribou hunting in the Mealy Mountains "gives us a meaning to get up in the morning. It really gave us-we look forward to it from year to year to year."

Several parents also discussed the stress of not being able to effectively share cultural knowledge with their children and grandchildren. As one parent explained, "I would be teaching my son how to do it [caribou hunt], too. Right now, it's something you can't—it's almost like a tradition that you can't pass on."

For many people, the caribou hunt was more holistic than solely the meat that it produced. As one person explained, "It's not the same to have just the meat. I think it's the process of the hunting, and the knowledge that come with it." Another interviewee elaborated further:

"You're not going to increase the quality of life of people just by having access to food, I think it's the part of what the food [means to Inuit]—-the interaction with the food, and food getting, and food preparation, and food sharing."

Many participants talked about the importance of sharing not only the experience of the caribou hunt with friends, family, and the broader community, but also the meat itself. The distribution and sharing of meat was identified as a key part of Inuit culture. As one person explained:

"Daddy always killed caribou. He used to always come back here and share [the meat] with the people, like his family. Even though it was legal [to hunt], but we used to share it out to our families when they couldn't get out and get it." 
A significant consequence of the hunting ban identified by participants, then, was a change to the way caribou meat is allocated throughout local food systems. Participants commented that they did not share caribou widely or openly anymore "because it's illegal now. It's illegal [to hunt], so they're giving [caribou] to their immediate family."

Many people discussed concerns about cultural erosion related to knowledge around the Mealy Mountain Caribou, particularly given how long the hunting ban has been in place. As one person stated, "It's too bad you couldn't have done [this research] twenty years ago, because you would have been able to talk to a lot of the older people who actually went in there and the hardships they went through." Another person shared this concern, and explained that:

"We have probably two or three people here in this community that's over 80 years old now and every year we're losing several people from each community in Nunatsiavut and once that knowledge is gone, it's all gone, is that what the government's waiting for?"

Given the concerns about cultural erosion and loss, several people discussed the need for all generations of Rigolet Inuit to be involved in maintaining the culture, particularly the youth: "If these young people are not given a chance to do that, they're not going to learn." Some parents talked about their plans to keep the knowledge of caribou and caribou hunting alive. As one father explained, "I'm definitely going to take her [his daughter] into the Mealy Mountains where we trap and take her to the herd. They've got some nice spots where I picked out now when she gets big." Continuing opportunities for connecting youth to caribou through time on the land observing and connecting with caribou was also identified as important by some parents and grandparents: "Observation is the very key thing to a lot of hunting, especially. I passed it onto my children and they know now what to do."

\section{3. "We're Made Criminals Just to Eat off the Land, Eat Our Food That Our Ancestors Ate": Criminalization, Enforcement, and Equity}

Participants described how people in Rigolet were not consulted when the ban on the Mealy Mountain Caribou herd was enacted. One participant spoke about coming home from a hunt and wildlife enforcement officers "stopped us and talked to us, [and they said] 'No more hunting caribou. These mountains are closed'." Another interviewee shared, "They [the government] just sort of force regulations on you." Many of the participants described the long duration of the hunting ban on the Mealy Mountain Caribou herd, and described continued consequences associated with the ban. As one participant explained:

"In this community of Rigolet, we know what a ban is like. We know what a ban is like and there's been several times that there's been raided [by enforcement officers]. This community has been raided so many times. They're looking for people and they're looking for caribou."

Most participants identified that living under the ban also led to being criminalized for harvesting a species that was previously paramount for survival. As one hunter explained, "Unfortunately some residents became criminals because they had to go and kill a caribou to survive and somebody told on him and they got their livelihood taken away."

The strong emotions associated with the ban and the consequences of wildlife enforcement were compounded when participants felt a sense of unfairness or inequity. For instance, some participants explained that they felt the hunting ban was not being enforced in a consistent way, both within and external to the community, which raised questions such as: "What's the point in putting a ban on it, if everyone is not going to abide with it, right?" Another participant further explained, "I think the process of equity around hunting is becoming massively tense. I think when it looks at where it should be coming from, how much should be had ... it's not applied across the board, it's creating tension." Another interviewee commented, "We all bleed the same. We all eat. We all live. We all got to pay bills. And, so, treat us all equal [for hunting ban enforcements]." Furthermore, while participants were not opposed to Indigenous Peoples illegally harvesting caribou for food security and cultural connections, 
participants did share particular frustration when acts of illegal harvesting were conducted in a way that countered Inuit values and culture, but still were not penalized by wildlife authorities. Examples of these situations included people hunting and then selling the animal; hunting a caribou and not sharing it; and excessive harvesting that put the sustainability of the caribou populations at risk.

Participants were not optimistic that the hunting ban on the Mealy Mountain Caribou herd was ever going to be lifted, which has created skepticism and distrust around how the caribou are managed. Given the frustrating experiences and concerns about not being consulted prior to the ban, some participants did not feel that the current hunting ban or management was sustainable. One participant explained:

"It pisses me off, to be quite frank with you. I believe in conservation and I don't want to be known as the person that killed the last caribou. But, I see what's going on and I've seen that for the last 50 years and we're farther back now than what we were 50 years ago. And, we're farther back now with the ban on the George River Caribou herd than what we were in 2013. So, it's obvious it's not working [current management strategies], not from my perspective or not from the people that I'm talking to."

\section{4. "We Talk until We're Blue in the Face": Consultation, Accommodation, and Ways Forward}

Throughout the interviews, Rigolet Inuit often described how they did not feel like they were "heard" when it came to their concerns regarding Mealy Mountain Caribou. Words such as "frustrated", "unnerving", "disheartening", "anger", "hurt", "it makes me sad sometimes", and "it depresses you" were all used in the context of the current caribou management system, and the ways in which Inuit were not consulted in decision-making. It was evident that the feelings associated with not being heard shaped perceptions of the current management of Mealy Mountain Caribou. For example, one participant explained:

"Well, I don't know if the government is focusing on anything. Just going out and doing these studies and saying there's only these many caribou here and -I don't believe that. I don't believe a thing that the government is saying."

Going further, another experienced hunter in the community explained:

"We haven't been able to participate into it [caribou management] and I've asked the question many times to different levels of government, all three different levels of government-federal, provincial and Nunatsiavut government-who the hell are you saving the caribou for? What are you saving them for? Work with the people rather than against the people. When you hear a government agency coming [into the community] for 50 plus years and tell you 'no, no, no, no' every time you put a request down, they say 'no you can't do this, you can't do that' well I mean that people, you can't work and you can't get constructive co-operation in that kind of an atmosphere. People right away put their backs up."

Participants emphasized the need for future action to include input from the community. As one participant explained, "You have to have the people in the communities [participate in decision-making]. The people who know the land and the people who participate, who hunt and who wants to ... be able to go on the land and connect." Another person stated, "We don't have no input into what's being done. We have to have input from the local communities, from who we are, our identity."

Many participants reflected on one particular incident that left many people feeling "not good", "sad", and "frustrated" when some Mealy Mountain Caribou became stranded on George's Island (Figure 2). An interviewee explained, "There were caribou out here on an island, George's Island. There was 500 [caribou] out there. They all died of starvation. Rather than let [Inuit] people kill them, the government rather let them die." When the community suggestions of a restricted hunt on the island went unheard, Inuit then questioned the Government's ability to manage caribou for sustainable utilization and to incorporate input from Inuit. 
Despite a strong sense of not feeling heard, many people described wanting to be involved in decision-making. Participants noted that "people are really wanting to sink their teeth into something" and "the Rigolet people will be the caretakers of that caribou." Participants regularly shared strong desires to protect caribou. As one hunter explained, "So, it's a choice you've got to make personally. But me, personally, I see both ways. I really want it for food and I really want it protected. That's how I feel about caribou."

Some Rigolet Inuit also saw opportunities for a leadership role in reconnecting with the Mealy Mountain region and caribou: "I really do think there's options for us to spearhead the movement around caribou, and not necessarily be informed of provincial bans." This participant elaborated further to say, "I think you can have living, breathing, moving conservation efforts that aren't on paper, that aren't enforced from what would seem to be third parties, that aren't just accessed by outside visitors, but are of the community."

Many conservation ideas emerged from participants, including monitoring, approaches to hunting and sharing caribou, and ways to pass on Inuit knowledge. During the community open house in March 2020, Rigolet Inuit prioritized Inuit-identified pathways forward for Mealy Mountain Caribou management (Figure 3). Suggestions regarding management approaches included ongoing monitoring of the Mealy Mountain Caribou, led by Rigolet Inuit and based on Inuit knowledge:

"Why can't they go up and monitor them every year? Like three, four, five people from town go up and see how they extended beyond their borders. What's the quality of the caribou moss this year, are their feeding grounds as healthy as we would expect? We had a really dry winter, we didn't have much snow, so are the bodies of water substantiated in there ... all those types of things. So, why can't we create capacity here through those processes and make us the stewards?"

For many participants, Inuit-led monitoring and stewardship provide important and healthy opportunities to be on the land:

"You know, we're supposed to be Inuit. Inuit are supposed to be on the land ... [it would be beneficial to] have a community hunt where we can go and we can participate into it and we can take people and we can feel happy, we can feel proud."

A number of participants discussed the idea of a limited, controlled hunt, to connect youth to caribou hunting and related knowledge, and to support Inuit food sharing and food security. As one participant explained, "I would like for them [youth] to see one day and maybe have a little harvest sometime." Participants explained that the idea of a community hunt would rely on sharing the meat equitably around the community: "Share it [caribou meat] out amongst the people. It wouldn't take away much, everybody around here to get a meal, you know, about 20. You know? Everybody is happy with a little bit of fry or roast or something." In addition to happiness, pride, and sharing, participants also described how a limited hunt could continue to facilitate cultural continuity and passing on traditional knowledge:

"A limited hunt, a cultural hunt you know, just to be out on the land, just to bring people on the land, to show them where the caribou live to. Certain times of year they move around, show them where they're feeding to, where their habitat is too and where they live to, because we know, we know those things." 


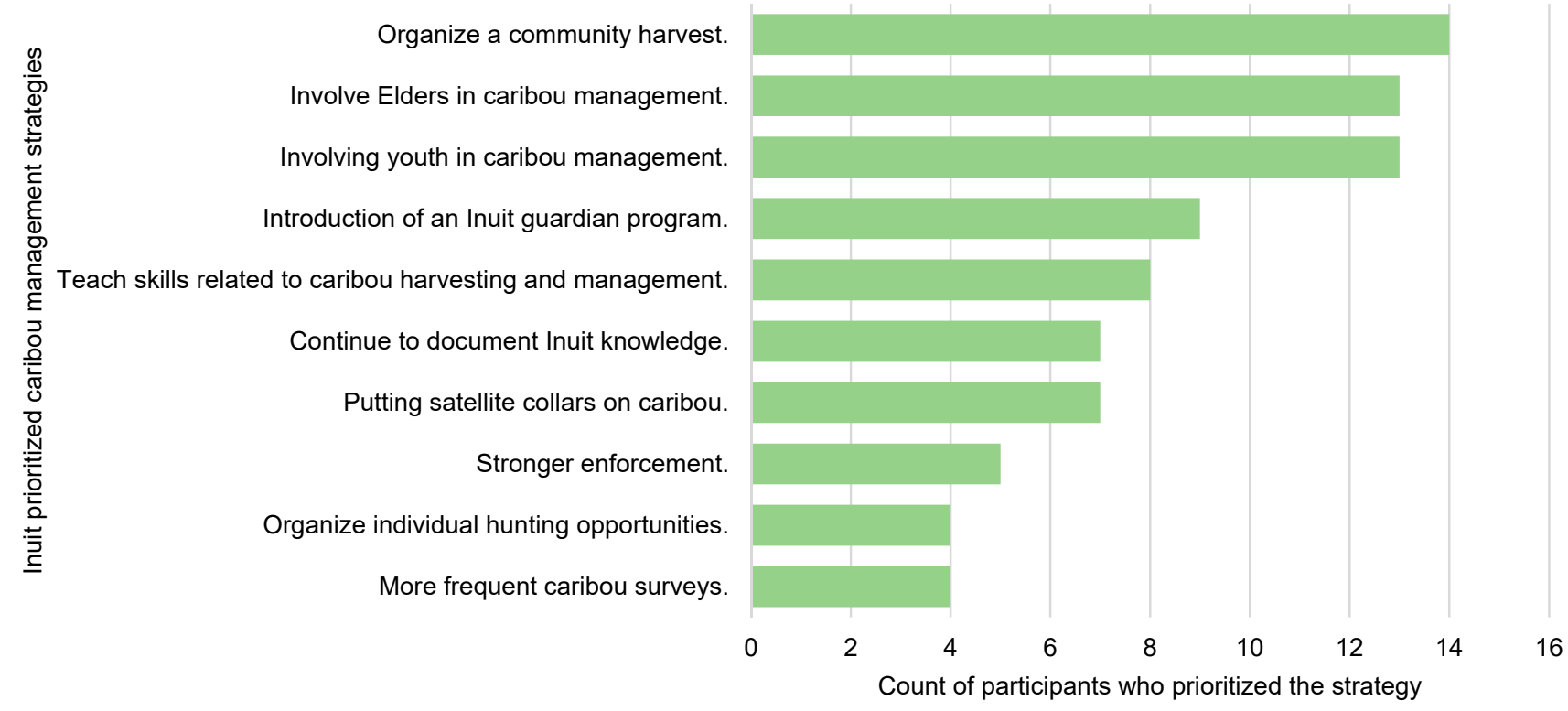

Figure 3. Rigolet Inuit identified and prioritized Mealy Mountain Caribou management strategies shared at the community open house in March 2020 ( $n=31$; numbers indicate total votes; selection options were not mutually exclusive). Note: while 37 people attended the open house, 6 people declined to participate in this strategy sharing and prioritizing activity. 


\section{Discussion}

Our results characterize the long-standing relationship that Rigolet Inuit have with Mealy Mountain Caribou, and how the practice of harvesting these caribou permeates their culture, is vital for cultural continuity, and has connections for well-being that extend beyond the clear implications for food security. Rigolet Inuit shared stories and memories with pride and described activities of hunting, preparing, sharing, and eating caribou [60] as important for health and well-being. Our results illustrate how the imposition of a hunting ban by the provincial Government with no Inuit collaboration has altered the Inuit-caribou relationship. For example, the longstanding hunting ban has had an effect on Inuit food security and Inuit culture [29], and as demonstrated by our results, also changed food sharing patterns, including the amount of meat shared, who it is shared with, and how it is shared. Given the deep importance of food sharing for maintaining social and familial bonds and supporting intergenerational learning, the disruption to food sharing networks of highly-valued cultural items, such as caribou meat, skin, bones, and antlers, has had significant and lasting negative effects on Inuit well-being and socio-cultural networks and practices.

Additionally, the hunting ban has also made many Inuit feel like "criminals" for participating in a cultural activity. Indeed, Rigolet Inuit expressed a sense of deep loss after the imposition of the hunting ban and the resulting criminalization of an important cultural practice [61], which overnight saw hunters move from being celebrated to being criminalized. These experiences are not isolated to Rigolet Inuit; Inuit in Nunavik, for example, have shared similar frustrations related to illegally harvesting culturally important wildlife such as caribou, polar bears, and other mammals [62]. This raises several questions, including whose laws are more relevant (the state or Indigenous laws), who owns the lands where harvesting is taking place, which rights take precedence, and which knowledge systems decide if an animal is in need of protection or not [62].

These results indicate that some caribou harvesting continues for household consumption for a variety of reasons, including as an active expression of Indigenous sovereignty and self-determination, as an expression of traditional land use rights, as a way to support food security and connections to cultural practices, and as a disagreement with wildlife regulations [63]. As Rigolet Inuit shared through this research, the presence of wildlife regulations did not mean the new laws were accepted or followed in the region by Indigenous Peoples, which is also reflected in wildlife biologist recognition of many harvests over the years [29], albeit little formal documentation of these harvests exist, perpetuating misconceptions and imprecise accounts of Indigenous caribou hunts [64]. Further, the criminalization of hunting Mealy Mountain Caribou over a sustained period of time has led to strong feelings about the necessity of Government wildlife management enforcement, and concerns that enforcement is not being implemented fairly. Concerns about equity in enforcement have increased tensions between and among Indigenous Peoples, both within Rigolet, and with other Indigenous communities in the region. In particular, Rigolet Inuit expressed concern and frustration about both local community members and members of other communities or Indigenous groups hunting and/or harvesting in disrespectful ways. While many people who were interviewed were not opposed to Indigenous Peoples harvesting caribou for food security and cultural connections while a hunting ban was in place, they were opposed to wasteful practices that conflicted with Inuit values and culture, and to the perceived differential enforcement of the hunting ban among different Indigenous Peoples and communities.

Rigolet Inuit had little involvement in early Mealy Mountain Caribou research efforts in the 1950s [28], or were not consulted on original management measures. Today's ongoing monitoring through western scientific methods [40] too often includes the bare minimum of Inuit consultation and involvement. In this context, Rigolet Inuit shared experiences of trying to inform caribou management efforts, only to feel unheard, silenced, ignored, and often powerless to fight against externally posed western conservation approaches that ignored Inuit traditional knowledge systems, and approaches to sustainably managing caribou. The stories that were shared resonate with the concept of "ethical loneliness" [65,66], or feeling abandoned by those who have the power to help compounded by the 
experience of not being heard. For Rigolet Inuit, this resulted in a missed opportunity for wildlife managers and Government officials to listen to the caribou stories, knowledge, and sciences of Rigolet Inuit and take action in a manner that enabled caribou conservation while supporting Inuit cultural continuity, food security, and well-being. Our research demonstrates that wildlife management must consider these other bodies of knowledge to understand how being ignored or not being heard "impacts how the past resonates in the present" [66]. Our research also highlights the diversity of ways of knowing and being with Mealy Mountain Caribou and for caribou management (i.e., ontological pluralism) [67], and illustrates that wildlife management strategies need to reflect the plurality of knowledge systems, perspectives, and ways of knowing, doing, and being for stronger health outcomes for both humans and animals.

Rigolet Inuit also expressed feelings of resentfulness for their losses, their treatment, and the lack of consideration and recognition of the importance of maintaining Inuit livelihoods, lifestyle, culture, identity, and well-being [68] clearly highlight the inequities and injustices in much of wildlife management and conservation. Recognizing this ethical loneliness and redressing the impacts of past decisions presents an urgent and critical challenge that current wildlife managers must begin to reverse and redress and find ways to rectify the impacts they caused; otherwise, this past will continue to affect the present for Inuit in Rigolet regarding the Mealy Mountain Caribou, as well as for other Indigenous Peoples who experience ethical loneliness resulting from the multi-generational impacts of colonization in the form of exclusionary and discriminatory wildlife management regimes and externally imposed management decisions.

These stories and Inuit knowledge from Rigolet demonstrate current and ongoing impacts resulting from experiences prior to modern day land claim agreements [69] and post 1980s jurisprudence when Indigenous rights advanced significantly [70]. Recent advancements in Indigenous rights and international guidelines [71-73] can and should influence the way wildlife management decisions are made and implemented; however, even with the settlement of modern-day land claim agreements, and the introduction of new processes such as co-management of resources, the state has retained the ultimate decision-making authority [47]. While perspectives and power can be balanced to a degree through co-management boards and initiatives, more work is required and, as our research shows, there could be mutual benefits for wildlife conservation and cultural sustainability if the state listens to-and respects and prioritizes-Indigenous Peoples' stories, histories, and knowledge, and lessens it authoritative grip on species that are so critical to Indigenous Peoples.

Although Rigolet Inuit indicated frustration and anger about being left out of previous decision-making processes, many people expressed optimism and strong ideas for moving forward with joint caribou management strategies, and with leadership from Inuit knowledge, sciences, and expertise (Figure 3).

First, many people suggested and prioritized a community organized harvest as an important management strategy that promotes caribou sustainability alongside Inuit health and well-being. Many people reflected on and shared positive stories about a community harvest in 1989 and believed organizing a similar community harvest—where the meat is shared—was still a good strategy. Both the Federal Species at Risk Act [73] and the Newfoundland and Labrador Endangered Species Act [74] have sections that permit the issuance of licenses for such a meaningful purpose, with reasons ranging from cultural continuity, caribou conservation, science, and public health. Second, Inuit prioritized the need for Inuit inclusion in decision-making processes, through the creation of both an Inuit guardian program and a program designed to bring Elders and youth together for shared learning, to support the management of Mealy Mountain Caribou. Third, through the implementation of these strategies, participants felt that Inuit knowledge should continue to be documented and skills be taught about caribou harvesting and management. As such, it became clear through these results that any future management approach without Inuit engagement would fail to support caribou sustainability and promote Inuit well-being. Finally, it should be highlighted that individual hunting licenses received 
the least amount of support from Rigolet Inuit, which reflects the Inuit value of sharing within the community and how wildlife enforcement has interfered with this practice.

Through this work, Rigolet Inuit are calling for collaboration between communities, a co-management board, levels of Inuit Government, and a Provincial Government to initiate action toward Inuit inclusion, cultural continuity, and the long-term sustainable utilization of the Mealy Mountain Caribou. The results from this research are being used to spark further dialogue that considers values, approaches, ethics, and implementation of new ideas, all of which will ultimately be needed to change the status quo. Special initiatives and success stories, where Inuit are leading caribou management and decision-making, could prove invaluable for conservation and restore a sense of value for the community to help repair damaged relationships and reclaim parts of Inuit identity.

Understanding the effects of the Mealy Mountain Caribou hunting ban hold lessons for other externally-imposed species moratoriums on Indigenous lands and the diverse and lasting negative socio-cultural and health impacts resulting from these management decisions-including, for example, the more recent hunting ban on the George River Caribou herd in Labrador in 2013, as well as many other government-imposed and enforced hunting bans. Indeed, the multi-generational and enduring negative effects of exclusionary and discriminatory Western management policies, enacted with little to no Indigenous involvement or consideration, is clear in this research, and illustrates not only the limitations of many western approaches to wildlife management, but the need for rectification and redress.

\section{Conclusions}

Through this research, Rigolet Inuit clearly articulated and demonstrated how colonial wildlife management decisions had disrupted important connections among caribou and Inuit, particularly related to food, culture, and well-being. Rigolet Inuit described their efforts to engage in caribou management decision-making, and expressed particular "frustration" and "hurt" with not being "heard", which created perceptions that current caribou management approaches were unfair, not inclusive, and put Inuit relationships with Mealy Mountain Caribou and related aspects of their cultural continuity at risk. In particular, Rigolet Inuit described the socio-cultural and emotional impacts of the criminalization of an important cultural practice, as well as perceived inequities in wildlife management enforcement. These results not only provide insights into the historical and ongoing experience of ethical loneliness related to wildlife management decisions and actions for a culturally important food-species, but they also demonstrate the long-term, multi-generational effects of externally imposed hunting moratoriums on food security, cultural continuity, and health and well-being.

Despite the past injustices and ongoing legacies of the hunting ban and colonial management practices, these results highlight opportunities to promote caribou sustainability and abundance, while simultaneously improving Inuit well-being and strengthening cultural continuity, not only for Rigolet Inuit, but also for other Indigenous Peoples globally who have been challenged and impacted by wildlife management decisions.

Author Contributions: Conceptualization, J.S., A.C., J.D.F., C.F., and S.L.H.; methodology, J.S., A.C., D.B., I.S., C.F., and S.L.H.; data collection, J.S., A.C., D.B., I.S., and C.T.R.F.; formal analysis, J.S., A.C., D.B., I.S., C.T.R.F., and S.L.H.; resources, J.S., A.C., and S.L.H.; writing-original draft preparation, J.S.; writing-review and editing, J.S., A.C., J.D.F., C.F., D.B., I.S., C.T.R.F., and S.L.H.; supervision, J.S., A.C., C.F., J.D.F., and S.L.H.; project administration, J.S., A.C., and S.L.H.; funding acquisition, J.S., A.C., and S.L.H. All authors have read and agreed to the published version of the manuscript.

Funding: This research was primarily funded by Environment and Climate Change Canada through the National Boreal Caribou Knowledge Consortium, with additional funding from the Social Sciences and Humanities Research Council, the Canadian Institutes for Health Research (CIHR), and the Canadian Mountain Network.

Acknowledgments: We thank the Rigolet knowledge holders who came to our open houses, engaged with this important topic, and shared their stories with our research team. We are grateful for the Rigolet Inuit Community Government letter of support, their time in reviewing the research results, and their support throughout the process. Thanks to: Amy Kipp for collecting interview data; Martin Shiwak for his land skills and guiding; 
David Wolfrey for his ongoing dialogue and support; Shawn Rivoire at the Torngat Secretariat for his GIS support; Alex Sawatzky for her graphic design and communication support; our funders at Environment and Climate Change Canada through the National Boreal Caribou Knowledge Consortium; and finally, thank you to the editors of this special issue and the reviewers for their helpful comments, and suggestions.

Conflicts of Interest: The authors declare no conflict of interest. The funders had no role in the design of the study; in the collection, analyses, or interpretation of data; in the writing of the manuscript, or in the decision to publish the results.

\section{References}

1. Lambden, J.; Receveur, O.; Kuhnlein, H.V. Traditional food attributes must be included in studies of food security in the Canadian Arctic. Int. J. Circumpolar Health 2007, 66, 308-319. [CrossRef]

2. Zoe, J. Ekwò and Tłıçho Nàowo/Caribou and Tłıçho language, culture and way of life: An evolving relationship and shared history. Rangifer Spec. Issue 2012, 20, 69-74.

3. Polfus, J.L.; Manseau, M.; Simmons, D.; Neyelle, M.; Bayha, W.; Andrew, F.; Andrew, L.; Kl,tsch, C.F.C.; Rice, K.; Wilson, P. Łeghágots'enete; (learning together): The importance of indigenous perspectives in the identification of biological variation. Ecol. Soc. 2016, 21. [CrossRef]

4. Meis Mason, A.; Dana, L.P.; Anderson, R. The Inuit commercial caribou harvest and related agri-food industries in Nunavut. Int. J. Entrep. Small Bus. 2007, 4, 785-806. [CrossRef]

5. Meis Mason, A.H.; Anderson, R.B.; Dana, L.-P. Inuit culture and opportunity recognition for commercial caribou harvests in the bio economy. J. Enterprising Communities People Places Glob. Econ. 2012, 6, 194-212. [CrossRef]

6. Kenny, T.-A.; Fillion, M.; Simpkin, S.; Wesche, S.D.; Chan, H.M. Caribou (Rangifer tarandus) and Inuit Nutrition Security in Canada. EcoHealth 2018, 15, 590-607. [CrossRef]

7. Hauer, G.; Adamowicz, W.L.; Boutin, S. Economic analysis of threatened species conservation: The case of woodland caribou and oilsands development in Alberta, Canada. J. Environ. Manag. 2018, 218, 103-117. [CrossRef]

8. Donovan, V.M.; Brown, G.S.; Mallory, F.F. The impacts of forest management strategies for woodland caribou vary across biogeographic gradients. PLoS ONE 2017, 12, e0170759. [CrossRef]

9. Barber, Q.E.; Parisien, M.A.; Whitman, E.; Stralberg, D.; Johnson, C.J.; St-Laurent, M.H.; Delancey, E.R.; Price, D.T.; Arseneault, D.; Wang, X.; et al. Potential impacts of climate change on the habitat of boreal woodland caribou. Ecosphere 2018, 9, e02472. [CrossRef]

10. Mameamskum, J. Assessment of Climate Change Impacts on the Caribou, the Land, and the Naskapi Nation, and Identification of Priority Adaptation Strategies; Canadian Electronic Library: Ottawa, ON, Canada, 2015.

11. Ford, J.; Couture, N.; Bell, T.; Clark, D. Climate change and Canada's north coast: Research trends, progress, and future directions. Environ. Rev. 2017, 26. [CrossRef]

12. Parlee, B.L.; Sandlos, J.; Natcher, D.C. Undermining subsistence: Barren-ground caribou in a "tragedy of open access". Sci. Adv. 2018, 4. [CrossRef] [PubMed]

13. COSEWIC. COSEWIC Assessment and Status Report on the Caribou Rangifer Tarandus, Barren-Ground Population, in Canada; Committee on the Status of Endangered Wildlife in Canada: Ottawa, ON, Canada, 2016.

14. Callaghan, C.; Virc, S.; Duffe, J. Woodland Caribou, Boreal Population, Trends in Canada. Canadian Biodiversity: Ecosystem Status and Trends 2010; Canadian Councils of Resource Ministers: Ottawa, ON, Canada, 2011.

15. IPBES. Summary for Policymakers of the Global Assessment Report on Biodiversity and Ecosystem Services of the Intergovernmental Science-Policy Platform on Biodiversity and Ecosystem Services; IPBES Secretariat: Bonn, Germany, 2019; p. 45.

16. COSEWIC. Recovery Strategy for Three Woodland Caribou Herds (Rangifer Tarandus Caribou; Boreal Population) in Labrador; Committee on the Status of Endangered Wildlife in Canada: Ottawa, ON, Canada, 2014.

17. Stankowich, T. Ungulate flight responses to human disturbance: A review and meta-analysis. Biol. Conserv. 2008, 141, 2159-2173. [CrossRef]

18. Polfus, J.L.; Hebblewhite, M.; Heinemeyer, K. Identifying indirect habitat loss and avoidance of human infrastructure by northern mountain woodland caribou. Biol. Conserv. 2011, 144, 2637-2646. [CrossRef]

19. Davison, T. Technical Report on the Cape Bathurst, Bluenose-West, and Bluenose-East Barren-Ground Caribou Herds Companion Report to Taking Care of Caribou: The Cape Bathurst, Bluenose-West, and Bluenose-East Barren-Ground Caribou Herds Management Plan; Government of the Northwest Territories: Inuvik, NT, Canada, 2015.

20. Kutz, S.J.; Hoberg, E.P.; Molnár, P.K.; Dobson, A.; Verocai, G.G. A walk on the tundra: Host-parasite interactions in an extreme environment. Int. J. Parasitol. Parasites Wildl. 2014, 3, 198-208. [CrossRef] 
21. Ljubicic, G.; Okpakok, S.; Robertson, S.; Mearns, R. Inuit Approaches to Naming and Distinguishing Caribou: Considering Language, Place, and Homeland toward Improved Co-management. Arctic 2018, 71, 309-333. [CrossRef]

22. Geist, V.; Mahoney, S.P.; Organ, J.F. Why Hunting Has Defined the North American Model of Wildlife Conservation. In Proceedings of Transactions of the North American Wildlife and Natural Resources Conference, 2001. pp. 175-185. Available online: https://wildlifemanagement.institute/store/product/64 (accessed on 29 September 2020).

23. Eichler, L.; Baumeister, D. Hunting for Justice: An Indigenous Critique of the North American Model of Wildlife Conservation. Environ. Soc. 2018, 9, 75. [CrossRef]

24. Peterson, M.N.; Nelson, M.P. Why the North American Model of Wildlife Conservation is Problematic for Modern Wildlife Management. Hum. Dimens. Wildl. 2017, 22, 43-54. [CrossRef]

25. COSEWIC. COSEWIC Assessment and Status Report on the Caribou Rangifer Tarandus, Eastern Migratory Population and Torngat Mountains Population, in Canada; Committee on the Status of Endangered Wildlife in Canada: Ottawa, ON, Canada, 2017; p. 68.

26. COSEWIC. COSEWIC Assessment and Status Report on the Caribou Rangifer Tarandus, Newfoundland Population, Atlantic-Gaspésie Population and Boreal Population, in Canada; Committee on the Status of Endangered Wildlife in Canada: Ottawa, ON, Canada, 2014; p. xxiii + 128 pp.

27. Bergerud, A.T. Management of Labrador Caribou. J. Wildl. Manag. 1967, 31, 621-642. [CrossRef]

28. Schmelzer, I. Recovery Strategy for Three Woodland Caribou Herds (Rangifer Tarandus Caribou; Boreal Population) in Labrador; Government of Newfoundland and Labrador: St. John's, NL, Canada, 2004.

29. Kulchyski, P.; Tester, F. Kiumajut (Talking Back). Game Management and Inuit Rights, 1950-70; UBC Press: Vancouver, BC, Canada, 2007.

30. Sandlos, J.K. Northern Wildlife, Northern People: Native Hunters and Wildlife Conservation in the Northwest Territories, 1894-1970. Ph.D. Thesis, York University, Ann Arbor, MI, Canada, 2004.

31. Li, S.; Smith, K. Inuit Fact Sheet for Inuit Nunangat; Canada, S., Ed.; Statistics Canada, 2016. 2016. Available online: http://www.statcan.gc.ca/pub/89-656-x/89-656-x2016014-eng.pdf (accessed on 29 September 2020).

32. Wood, M. Beneficiary Statistics; Snook, J., Ed.; Personal Communications: Happy Valley-Goose Bay, NL, Canada, 2019.

33. Canada, S.; Rigolet, T. Newfoundland and Labrador (table). Aboriginal Population Profile. Available online: http://www12.statcan.gc.ca/census-recensement/2016/dp-pd/abpopprof/index.cfm?Lang=E (accessed on 31 May 2020).

34. Cunsolo Willox, A.; Harper, S.L.; Edge, V.L.; Landman, K.; Houle, K.; Ford, J.D. The land enriches the soul: On climatic and environmental change, affect, and emotional health and well-being in Rigolet, Nunatsiavut, Canada. Emot. Space Soc. 2013, 6, 14-24. [CrossRef]

35. Cunsolo Willox, A.; Harper, S.L.; Ford, J.D.; Landman, K.; Houle, K.; Edge, V.L. "From this place and of this place": Climate change, sense of place, and health in Nunatsiavut, Canada. Soc. Sci. Med. 2012, 75, 538-547. [CrossRef]

36. Fitzhugh, L.D. The Labradorians. In Voices from the Land of Cain; Breakwater: St. John's, NL, Canada, 1999.

37. Rigolet Inuit Community Government. History of Rigolet. Available online: http://www.townofrigolet.com/ home/ (accessed on 25 November 2019).

38. FLR. Mealy Mountain Boreal Caribou. In March 2019 Survey Findings; Fisheries and Land Resources: Happy Valley-Goose Bay, NL, Canada, 2019.

39. Schmelzer, I.; Wright, C. An Estimate of Population Size and Trend for the Mealy Mountain Caribou Herd; Department of Environment and Conservation: Corner Brook, NL, Canada, 2012.

40. Berkes, F. Sacred Ecology: Traditional Ecological Knowledge and Resource Management; Taylor \& Francis: Abingdon, UK, 1999.

41. Newing, H. Conducting Research in Conservation: Social Science Methods and Practice; Routledge: London, UK, 2011. [CrossRef]

42. Jacobson, S.K.; McDuff, M.; Monroe, M. Conservation Education and Outreach Techniques; Oxford University Press: Oxford, UK, 2015. [CrossRef]

43. Bennett, N.J.; Roth, R.; Klain, S.C.; Chan, K.M.A.; Clark, D.A.; Cullman, G.; Epstein, G.; Nelson, M.P.; Stedman, R.; Teel, T.L.; et al. Mainstreaming the social sciences in conservation. Conserv. Biol. 2017, 31, 56-66. [CrossRef] [PubMed] 
44. Berkes, F. Evolution of co-management: Role of knowledge generation, bridging organizations and social learning. J. Environ. Manag. 2009, 90, 1692-1702. [CrossRef] [PubMed]

45. Berkes, F. Devolution of environment and resources governance: Trends and future. Environ. Conserv. 2010, 37, 489-500. [CrossRef]

46. White, G. Indigenous Empowerment through Co-Management. Land Claim Boards, Wildlife Management, and Environmental Regulation; UBC Press: Vancouver, BC, Canada, 2020.

47. Snook, J.; Cunsolo, A.; Dale, A. Co-management led research and sharing space on the pathway to Inuit self-determination in research. North. Public Aff. 2018, 6. Available online: http://www.northernpublicaffairs.ca/index/volume-6-issue-1/co-management-led-research-andsharing-space-on-the-pathway-to-inuit-self-determination-in-research/ (accessed on 29 September 2020).

48. Inuit Tapiriit Kanatami. National Inuit Strategy on Research; Inuit Tapiriit Kanatami: Ottawa, ON, Canada, 2018.

49. Battisti, C. How to make (in)effective conservation projects: Look at the internal context. Anim. Conserv. 2017, 20, 305-307. [CrossRef]

50. Rust, N.A.; Abrams, A.; Challender, D.W.S.; Chapron, G.; Ghoddousi, A.; Glikman, J.A.; Gowan, C.H.; Hughes, C.; Rastogi, A.; Said, A.; et al. Quantity Does Not Always Mean Quality: The Importance of Qualitative Social Science in Conservation Research. Soc. Nat. Resour. 2017, 30, 1304-1310. [CrossRef]

51. Conrad, F. What is Conversational Interviewing? Sage Publications Ltd.: London, UK, 2011. [CrossRef]

52. Chambers, R. Participatory Mapping and Geographic Information Systems: Whose Map? Who is Empowered and Who Disempowered? Who Gains and Who Loses? Electron. J. Inf. Syst. Dev. Ctries. 2006, 25, 1-11. [CrossRef]

53. Tobias, T.N. Living Proof: The Essential Data-Collection Guide for Indigenous Use-and-Occupancy Map Surveys; Ecotrust Canada: Vancouver, BC, Canada, 2009.

54. Bazeley, P.; Richards, L. The NVIVO Qualitative Project Book; SAGE Publications Ltd.: London, UK, 2000.

55. Thorpe, R.; Holt, R. The SAGE Dictionary of Qualitative Management Research; SAGE Publications Ltd.: London, UK, 2008. [CrossRef]

56. Fereday, J.; Muir-Cochrane, E. Demonstrating Rigor Using Thematic Analysis: A Hybrid Approach of Inductive and Deductive Coding and Theme Development. Int. J. Qual. Methods 2006, 5. [CrossRef]

57. Mathison, S. Constant Comparative Method. In Encyclopedia of Evaluation; Sage Publications Inc.: Thousand Oaks, CA, USA, 2005. [CrossRef]

58. Creswell, J.W.; Miller, D.L. Determining Validity in Qualitative Inquiry. Theory Pract. 2000, 39, 124-130. [CrossRef]

59. King, U.; Furgal, C. Is hunting still healthy? Understanding the interrelationships between Indigenous participation in land-based practices and human-environmental health. Int. J. Environ. Res. Public Health 2014, 11, 5751-5782. [CrossRef]

60. Cunsolo, A.; Borish, D.; Harper, S.L.; Snook, J.; Shiwak, I.; Wood, M. The Herd Caribou Project Steering Committee. "You can never replace the caribou": Inuit Experiences of Ecological Grief from Caribou Declines. Am. Imago 2020, 77, 31-59. [CrossRef]

61. Gombay, N. 'Poaching'-What's in a name? Debates about law, property, and protection in the context of settler colonialism. Geoforum 2014, 55, 1-12. [CrossRef]

62. Muth, R.M.; Bowe, J.F. Illegal harvest of renewable natural resources in North America: Toward a typology of the motivations for poaching. Soc. Nat. Resour. 1998, 11, 9-24. [CrossRef]

63. Campbell, C. A Genealogy of the Concept of 'Wanton Slaiugther' in Canadian Wildlife Biology. In Cultivating Arctic Landscapes. Knowing and Managing Animals in the Circumpolar North; Anderson, D.G., Nuttall, M., Eds.; Berghahn Books: New York, NY, USA, 2004.

64. Stauffer, J. Building Worlds/Thinking Together about Ethical Loneliness. Philos. Today 2018, 62, 717-731. [CrossRef]

65. Stauffer, J. Ethical Loneliness: The Injustice of Not Being Heard; Columbia University Press: New York, NY, USA, 2016.

66. Harrison, R. Beyond 'Natural' and 'Cultural' Heritage: Towards an Ontological Politics of Heritage in the Age of Anthropocene. Herit. Soc. 2015, 8, 24-42. [CrossRef]

67. Jeffery, R.; Otto, R.; Phillips, F. George's Island, Labrador-A high-density predator-free refuge for a woodland caribou subpopulation? Rangifer 2007, 27, 6. [CrossRef]

68. Minister of Indian Affairs and Northern Development. Labrador Inuit Land Claims Agreement; Minister of Indian Affairs and Northern Development: Ottawa, ON, Canada, 2005.

69. Borrows, J. Crown and Aboriginal Occupations of Land: A History E Comparison; Ipperwash Inquiry: Toronto, ON, Canada, 2005; p. 85. 
70. Borrini-Feyerabend, G.; Kothari, A.; Oviedo, G. Indigenous and Local Communities and Protected Areas: Towards Equity and Enhanced Conservation; IUCN: Gland, Switzerland; Cambridge, UK, 2004.

71. Beltrán, J. Indigenous and Traditional Peoples and Protected Areas. In Principles, Guidelines and Case Studies; World Commission on Protected Areas: Gland, Switzerland, 2000; p. 133.

72. Wild, R.; McLeod, C. Sacred Natural Sites. In Guidelines for Protected Area Managers; IUCN: Gland, Switzerland, 2008.

73. Minister of Justice. Species at Risk Act. In S.C. 2002, c. 29; Minister of Justice: Ottawa, ON, Canada, 2002.

74. Queens Printer. Endangered Species Act. In SNL2001 Chapter E-10.1; Queens Printer: St. John's, NL, Canada, 2001.

(C) 2020 by the authors. Licensee MDPI, Basel, Switzerland. This article is an open access article distributed under the terms and conditions of the Creative Commons Attribution (CC BY) license (http://creativecommons.org/licenses/by/4.0/). 